\title{
DIETARY SUCROSE DEFINES LIFESPAN AND METABOLISM IN DROSOPHILA
}

\author{
O. STRILBYTSKA, T. STRUTYNSKA, U. SEMANIUK, \\ N. BURDYLIYK, O. LUSHCHAK ${ }^{\bowtie}$ \\ Vasyl Stefanyk Precarpathian National University, Ivano-Frankivsk, Ukraine; \\ 凶e-mail: oleh.lushchak@pnu.edu.ua
}

Received: 28 February 2020; Accepted: 25 June 2020

\begin{abstract}
Nutrition affects various life-history traits. We used fruit flies Drosophila melanogaster to determine whether life-history traits, particularly life span and metabolism, are affected by dietary sucrose content. We fed flies by four different diets containing constant yeast concentration and increasing amounts of sugar ranged from $1 \%$ to $20 \%$. We found that low sucrose diet increases female lifespan. We also showed, that low dietary sucrose maximized malate dehydrogenase, aspartate aminotransferase activity in males and lactate dehydrogenase activity in females. In addition, dietary carbohydrate has a considerable impact on urea level, suggesting that dietary carbohydrate impacts overall metabolism. Our findings revealed the influence of dietary sugar on metabolic enzymes activities, indicating an existence of optimal nutritional conditions for prolongevity phenotype and confirming an important impact of dietary sugar on life-history traits.
\end{abstract}

Ke y wo rds: nutrition, diet, carbohydrate, lifespan, metabolism, fruit fly Drosophila.

$\mathrm{D}$ iet and nutritional factors largely influence the biochemical parameters of the body, which results in various physiological changes. Many diseases are associated with nutritional imbalance, according to this a majority of experimental approaches are focused on nutritional aspects and metabolic regulation. Balance between macronutrients is very important factor affecting fruit fly longevity $[1,2]$. In Drosophila, it was demonstrated that protein content in the diet is the main dietary determinant of lifespan, but carbohydrates have little or no effect [3, 4]. However, recent studies indicate that carbohydrates also play a central role in determining life expectancy and maintaining health [5]. There are evidences, that different amount of sucrose in the diet results in distinct changes in the body $[2,6]$. Moreover, the type of carbohydrate consumed has also important impact on physiological and metabolic processes [7]. Some of these changes are resemble to those complications observed in cardiovascular diseases and diabetes. It is known that high dietary sucrose disrupts the ho- meostasis of glucose metabolism in the body and causes obesity [8]. However, low sucrose consumption can induce mild oxidative stress [9].

Dietary regimens with low or high carbohydrate concentration lead to activation or inhibition of nutrient-sensing signaling pathways. If carbohydrate level in the diet is low it results in activation of AMPK (AMP-activated protein kinase) pathway, which is known to be an energy sensor that promotes transcriptional reprograming of the cells and their metabolic adaptation to external factors [10]. Activated AMPK turns on catabolic pathways to generate ATP and inhibits ATP-consuming anabolic processes that are not required for the immediate survival of the cell. In the short term, this occurs by stimulating glycolysis and the oxidation of fatty acids, and in the long term, by stimulating mitochondrial biogenesis [10]. Carbohydrates availability and insulin signaling have been shown to be important factors in regulating lifespan, growth and body size [11]. Characterization of the body's response to various nutritional conditions can be useful for

(C) 2020 Strilbytska O. et al. This is an open-access article distributed under the terms of the Creative Commons Attribution License, which permits unrestricted use, distribution, and reproduction in any medium, provided the original author and source are credited. 
understanding the mechanisms underlying the metabolic disease and for developing pharmacological interventions or treatment methods.

Fruit flies have become a promising model for studying the effects of dietary components on various physiological characteristics, including lifespan and metabolism. In studies on Drosophila, new important knowledge was gained that the fundamental relationships between life-history traits are mediated by macroelements [12]. Using this model organism in the nutrition experiments help us to understand the relationship between human nutrition and metabolic disorders.

Here we investigated biochemical parameters and lifespan in Drosophila melanogaster when consuming diets with different concentrations of sucrose ranged from 1 to $20 \%$. We observed, that low carbohydrate consumption maximized fly lifespan. Alanine aminotransferase (ALT), aspartate aminotransferase (AST), lactate dehydrogenase (LDH) and malate dehydrogenase (MDH) were measured on a series of diets with varying sugar content to analyze the course of the main metabolic processes. Our study demonstrated, that the low dietary concentration of a particular nutrient in some cases correlates with increased enzymes activities. Interestingly, our study suggested that fly metabolism is driven by a daily caloric intake and our results considered a great impact of macronutrients ratio in aging process.

\section{Materials and Methods}

Insects, maintaining and conditions. We used CantonS (D. melanogaster Meigen) flies which were received from the Bloomington Stock Center (Indiana University, USA). All flies were grown on the medium that contains $4 \%$ sucrose, $4 \%$ dry yeast, $1.2 \%$ agar and $0.18 \%$ nipagin as an anti-fungal agent. Flies were reared at $25^{\circ} \mathrm{C}$ and relative humidity of $60-70 \%$ on a $12 \mathrm{~h}$ day/night cycle [13]. Flies aged 4 days were separated by sex and kept on the abovementioned medium for one more day to recovery after $\mathrm{CO}_{2}$ anesthesia. Than 5-days old flies were placed at standard densities of 200 flies per $1.5 \mathrm{~L}$ demographic cages. Cages were supplemented with $25 \mathrm{ml}$ plastic vial filled with the $5 \mathrm{ml}$ of experimental medium, containing $4 \%$ of dry yeasts and different

Abbreviations: LDH, lactate dehydrogenase; $\mathrm{MDH}$, malate dehydrogenase; ALT, alanine aminotransferase; AST, aspartate aminotransferase; AKH, adipokinetic hormone; IS, insulin signaling. sucrose concentrations: $1 \%, 4 \%, 10 \%, 20 \% ; 1.2 \%$ of agar, $0.18 \%$ of nipagin. On the 25 -th day of the experiment flies were frozen in the liquid nitrogen for subsequent measurements. For measurements pre-weighted flies were homogenized in $10 \mathrm{mM}$ of ice-cold sodium phosphate buffer $(\mathrm{pH}=7.4)$ (ratio 1:10) with further centrifugation (16 $000 \mathrm{~g}, 15 \mathrm{~min}$, $4^{\circ} \mathrm{C}$ ). Supernatants were used to measure biochemical parameters.

Lifespan assay. Flies of both sexes were maintained separately under the conditions, described above. The experimental mediums were changed every second day and dead flies were counted. We conduct two independent lifespan tests, and made survival curves for each group with flies that consumed different concentration of sucrose; there were approximately 150 flies in each group for each replicate.

Determination of enzymatic activities. Malate dehydrogynase (MDH, EC 1.1.1.37) and lactate dehydrogynase (LDH, EC 1.1.1.27) activities were determined by a decrease in absorbance at $340 \mathrm{~nm}$ resulting from the oxidation of NADH [14]. Measurements were carried on Specol 211 (Jena, Germany) at $340 \mathrm{~nm}$ and all calculations were made using an extinction coefficient of $6220 \mathrm{M}^{-1} \cdot \mathrm{cm}^{-1}$. Alanine transaminase (ALT, EC 2.6.1.2) and aspartate transaminase (AST, EC 2.6.1.1) activities were measured spectrophotometrically by using the commercial kits (PZ Cormay S.A., Poland) and Specol 211 spectrophotometer (Jena, Germany). The ALT and AST activities were assayed by the rate of NADH oxidation, which is proportional to the reduction in absorbance at $340 \mathrm{~nm}$ over time $(\triangle \mathrm{OD} 340 \mathrm{~nm} /$ min). The activities of MDH, LDH, ALT and AST were presented as international units (or milliunits) per milligram of soluble protein (mU/mg protein).

Determination of urea. Spectrophotometric method was used for urea determination. This method is based on the monitoring of NADH concentration that is used during hydrolysis of urea by urease. Changes in absorbance was recorded on Specol 211 (Jena, Germany) at $340 \mathrm{~nm}$ and calculation was made using an extinction coefficient of $6220 \mathrm{M}^{-1} \cdot \mathrm{cm}^{-1}$. Urea content was expressed as nanogram per milligram of wet mass ( $\mathrm{ng} / \mathrm{mg} \mathrm{wm}$ ).

Statistical analysis and graphical representation. Experimental data are presented as mean \pm SEM and $P<0.05$ is considered as significantly different. Statistical analysis was performed using "Prism" (GraphPad Software, Inc.). Tukey's multiply comparison test has been used to compare 
activities of LDH, MDH, ALT, AST and urea concentration. Log rank test was used to analyze lifespan curves. All graph were generated in "GraphpadPrism7".

\section{Results and Discussion}

Dietary sucrose influence on lifespan of female flies. Longevity is determined by general functional state of the organism as result of its interaction with different environmental factors. Shifts in dietary macronutrients ratio lead to changes in functioning of signaling pathways, which, in turn, regulate Drosophila lifespan $[15,16]$. Consumption of diet with $1 \%$ of sucrose significantly increases lifespan in fly females as compared to those reared on the 4 or $10 \%$ (log-rank test, $P=0.045 ; \chi^{2}=4.007$ ) (Fig. $1, B$ ). We observed decreased survival of females fed on $20 \%$ sucrose as compared with the 4 and $10 \%$ sucrose (log rank, $P<0.001 ; \chi^{2}=12.28$ ) (Fig. 1, B). Our results showed, that dietary conditions had no impact on survival of male flies (Fig. 1, A).

Mean lifespans were associated with gender (two-way ANOVA; $\mathrm{F}_{3,1086}=134, P=0.0001$ ), sucrose concentration in the diet $\left(\mathrm{F}_{1,1086}=1208, P<0.0001\right)$ and with interaction of both abovementioned factors $\left(\mathrm{F}_{3,1086}=206.3, P<0.0001\right)$. Male flies, which consumed $1 \%$ sucrose had lower mean lifespan compared with the rest experimental cohorts (Fig. 2, A; $P<0.05)$. Mean lifespan of males increased in the following order: $20 \%<10 \%<4 \%<1 \%$ (Fig. 2, A). However, in females the highest mean lifespan was detected in group, which consumed medium with $10 \%$ sucrose. Mean life span of females increased in the following order: $20 \%<4 \%<1 \%<10 \%$ (Fig. 2, A). We did not find any significant changes in maxi-

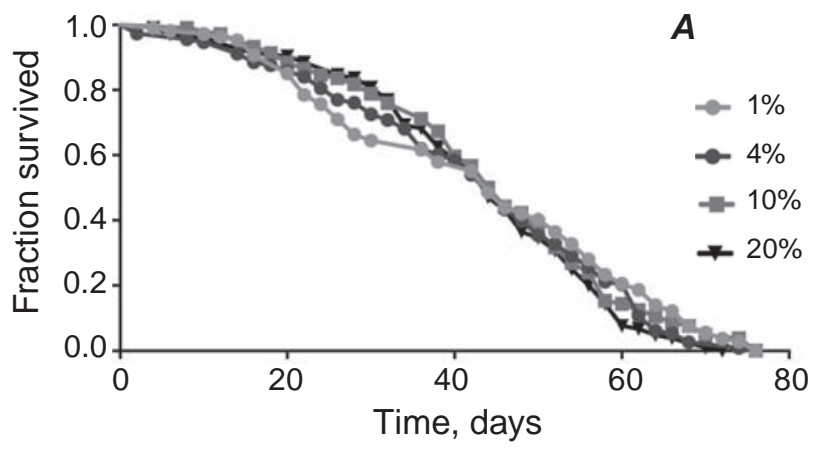

mal lifespan in both male and female flies, which consumed mediums with different sucrose content (Fig. 2, B).

MDH and LDH activities are affected by dietary sucrose. Enzymes which are involved in carbohydrate metabolism including LDH (lactate dehydrogenase) and MDH (malate dehydrogenase) are known to be influenced by nutritional and dietary status. MDH and LDH are two homologous enzymes, which belong to a wide group of 2-ketoacid:NAD(P)-dependent dehydrogenases that catalyze the reversible conversion of 2-hydroxyacids to the corresponding 2-ketoacids and are involved in energy metabolism [17].

LDH activity was dependent on gender $\left(\mathrm{F}_{3,24}=3.99, P=0.193\right)$, sucrose concentration in the $\operatorname{diet}\left(\mathrm{F}_{1,24}=27.73, P<0.0001\right)$, and interaction of both factors $\left(\mathrm{F}_{3,24}=7.649, P=0.0009\right)$. The activity of LDH was not affected by dietary sucrose in male flies. The lower activity of LDH was detected in females, which consumed medium with $4 \%$ and $10 \%$ of sucrose as compared to the $1 \%$ of sucrose (Fig. 3 , $A ; P<0.05)$. Thus, with decreasing sucrose concentration, $\mathrm{LDH}$ activity increases.

MDH activity strongly depended on the fly gender $\left(\mathrm{F}_{3,24}=4.503, P=0.012\right)$, sucrose concentration $\left(\mathrm{F}_{1,24} \stackrel{3,24}{=} 60.67, P<0.0001\right)$ and interaction of both factors $\left(\mathrm{F}_{3,24}=3.879, P=0.022\right)$. We observed higher $\mathrm{MDH}$ activity in males, which consumed medium with $1 \%$ sucrose as compared to those that consumed medium with $20 \%$ sucrose (Fig. $3, B ; P<0.05$ ). $\mathrm{MDH}$ activity was not affected by sucrose concentration in the diet of females.

ALT and AST activities. Aminotransferases are enzymes that transfer $\alpha$-amino group from the

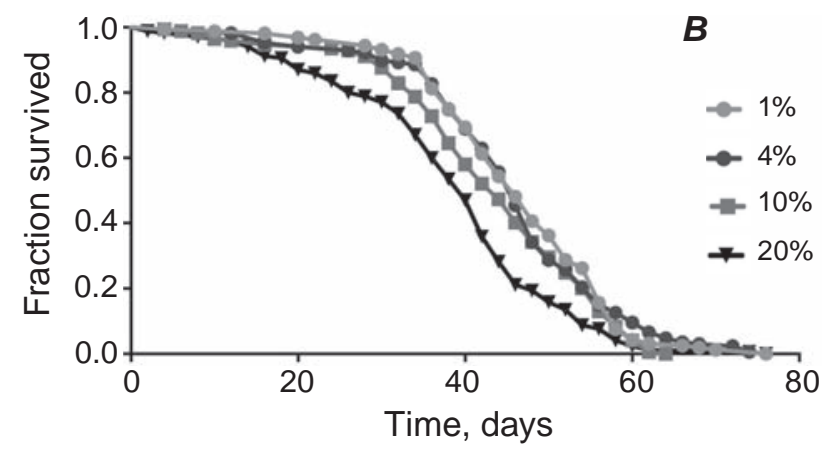

Fig. 1. Life span of male (A) and female (B) flies fed on diets with different concentrations sucrose (1\%, 4\%, $10 \%, 20 \%$ ) and constant yeast content (4\%). Each curve shows the fraction of individuals alive as a function of age with about 200 flies per group. Statistical analysis of differences in survival was conducted with a logrank test 

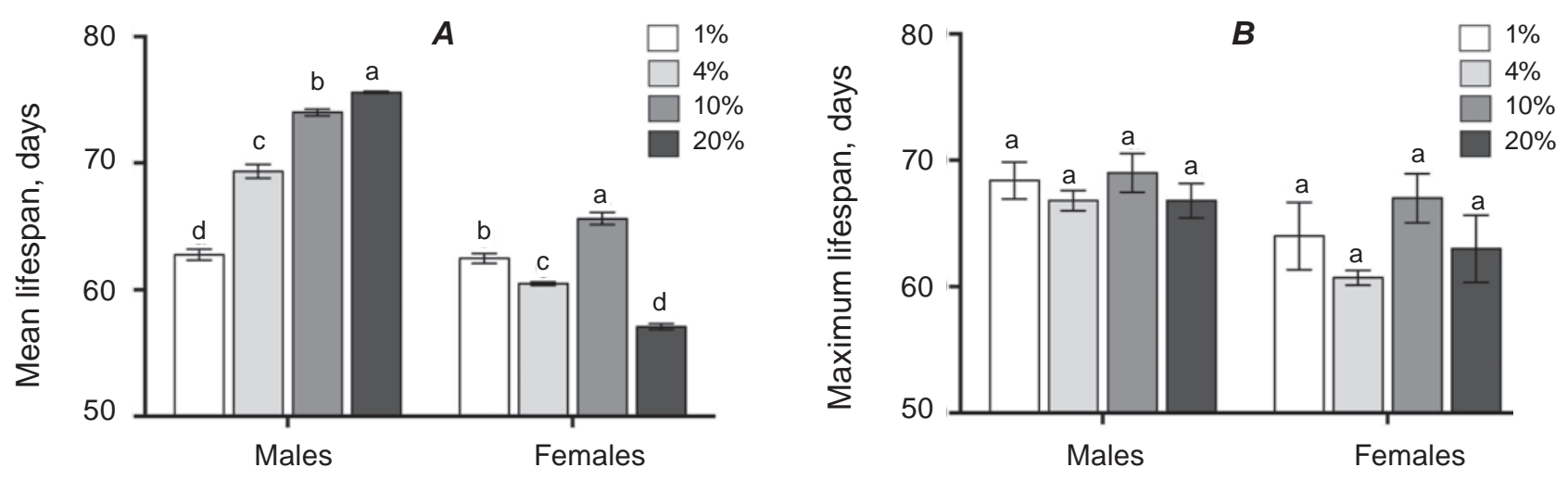

Fig. 2. Mean (A) and maximum (B) lifespans of flies fed on diets with different sucrose concentrations. Results are presented as mean \pm SEM. Values were compared by the Tukey's test: $\boldsymbol{a}$-indicates the highest values among all tested groups; $\boldsymbol{b}$ - significant difference from $\boldsymbol{a}$ with $P<0.05 ; \boldsymbol{c}$ - significant difference from $\boldsymbol{a}$ and $\boldsymbol{b}$ with $P<0.05 ; \boldsymbol{d}$ - significant difference from $\boldsymbol{a}, \boldsymbol{b}, \boldsymbol{c}$ with $P<0.05$

amino acid to $\alpha$-ketoacid. ALT and AST belong to the pyridoxal-phosphate-dependent aminotransferase [17]. In Drosophila, changes in ALT and AST activities are mostly associated with cell damage and changes in metabolic processes [18]. However, different concentrations of sucrose in the diet affect AST activity in male flies. We observed higher AST activity in males, which consumed medium with $1 \%$ sucrose compared to groups, which consumed mediums with 10 and $20 \%$ sucrose (Fig 4, B; $P<0.05)$. AST activity was significantly decreased in the males, which were reared on the medium with $20 \%$ sucrose as compared to $4 \%$ sucrose (Fig. 5, B; $P<0.004)$. Consequently, increased AST activity is associated with decreased sucrose concentration in the experimental medium. The activity of ALT was not affected by sucrose concentration in both sexes (Fig. 4, A).

Urea content. Urea plays an important role in the metabolism of nitrogen-containing compounds in animals and is the main nitrogen-containing substance in the urine of mammals [19]. The content of urea can change due to shifts in protein-to-carbohydrate ratio in the diet [20]. Urea concentration in flies significantly depended on sucrose concentration in the diet $\left(\mathrm{F}_{1,24}=50.44, P<0.0001\right)$, fly gender $\left(\mathrm{F}_{3,24}=6.488, P \stackrel{0.002)}{=}\right.$ and interaction between sex and diet $\left(\mathrm{F}_{3,24}=4.838, P=0.009\right)$. Males that consumed medium with $1 \%$ sucrose displayed higher urea content as compared to $10 \%$ sucrose (Fig 5;
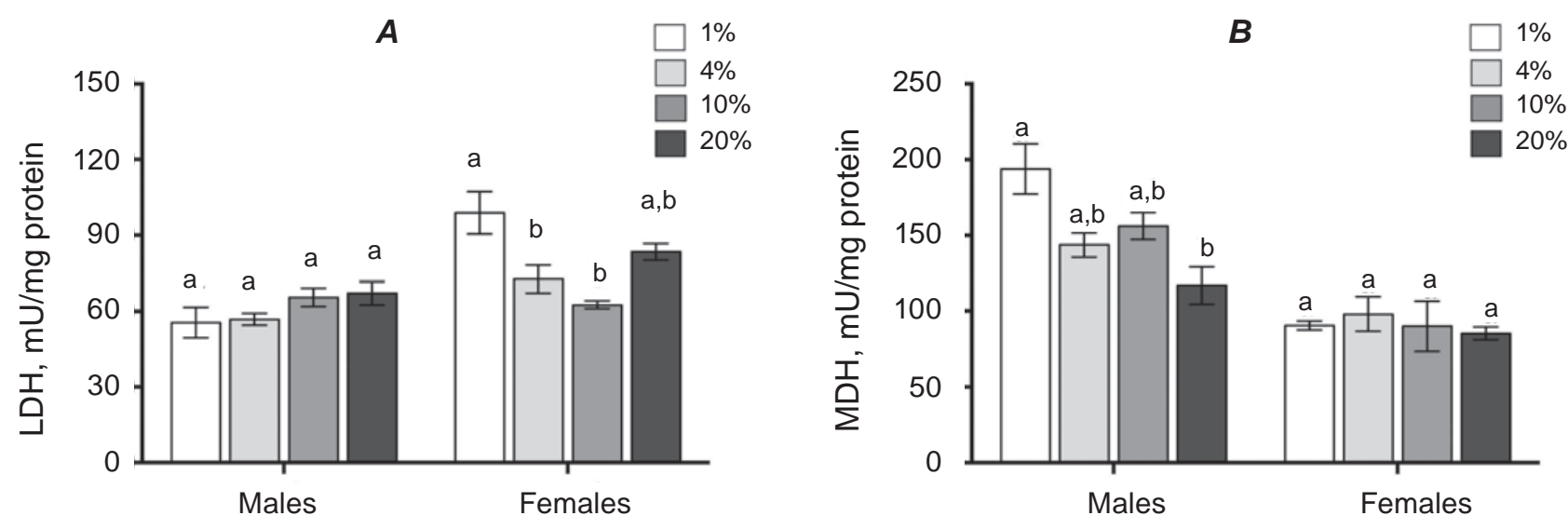

Fig. 3. $\mathrm{LDH}$ (A) and $\mathrm{MDH}$ (B) activities in flies that consumed diets with different sucrose concentrations. Results are shown as mean $\pm S E M, n=4$. Values were compared by the Tukey's test: $\boldsymbol{a}$-indicates the highest mean among all tested groups; $\boldsymbol{b}$ - indicates a significant difference from $\boldsymbol{a}$ with $P<0.05$ 

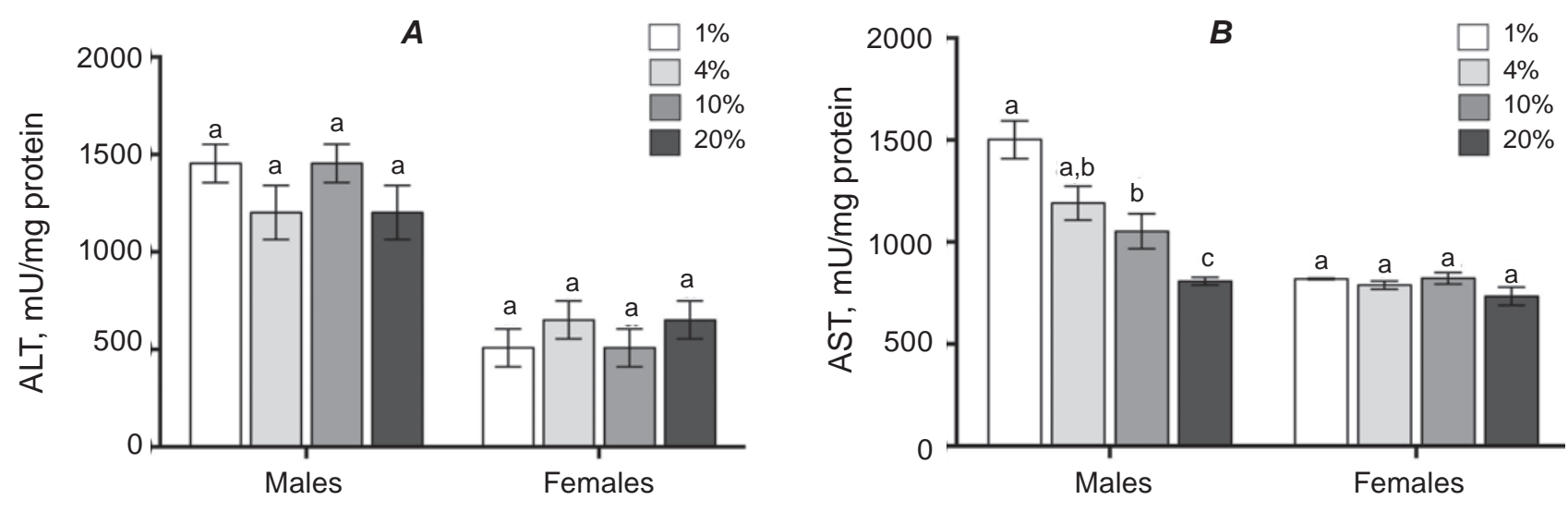

Fig. 4. Activities of ALT (A) and AST (B) in flies under consumption of dietary regimens with different sucrose concentration. Results are presented as mean $\pm S E M, n=4$. Values were compared by the Tukey's test: $\boldsymbol{a}-$ indicates the highest mean among all tested groups; $\boldsymbol{b}$-indicates a significant difference from $\boldsymbol{a}$ with $P<0.05$; $\boldsymbol{c}$-indicates a significant difference from $\boldsymbol{a}$ and $\boldsymbol{b}$ with $P<0.05$

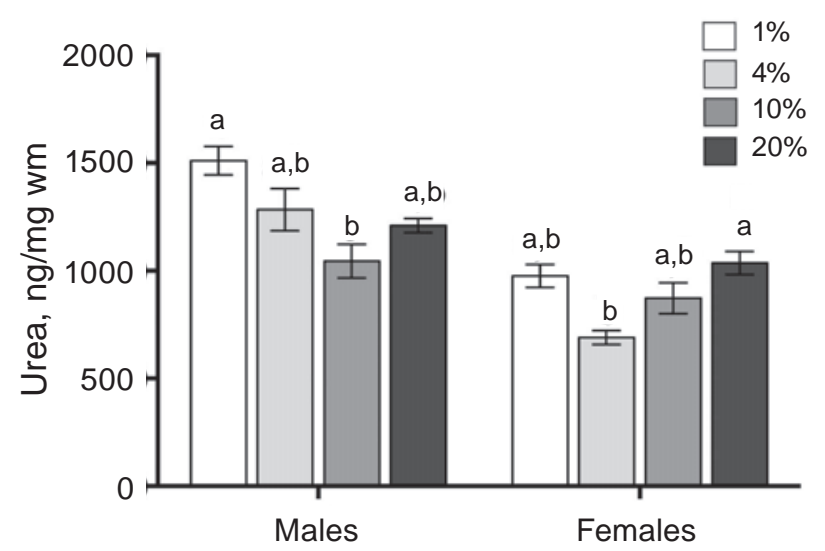

Fig. 5. Effects of dietary sucrose on urea content in fly. Results are presented as mean $\pm S E M, n=4$. Values were compared by the Tukey's test: $\boldsymbol{a}$ - indicates the highest mean among all tested groups; $\boldsymbol{b}$ - indicates a significant difference from $\boldsymbol{a}$ with $P<0.05$

$P<0.05)$. Females, which were reared on the medium with $20 \%$ of sucrose had higher urea content compared to those fed on $4 \%$ sucrose.

Lifespan is critically determined by diet composition mostly by balance between protein and carbohydrate. Numerous studies have shown that changes in dietary concentrations of yeast (a source of protein) and sucrose, as well as their ratio, can have a significant effect on lifespan [2, 21]. Understanding the interactions between diet and longevity is critical for protecting against the rising incidence of age-related metabolic disease.
Our results showed that lower sucrose concentration in the diet caused lifespan extension in fruit fly. The longevity phenotype in flies, which consumed low calorie diet is accompanied with higher activities of metabolic enzymes such as LDH, MDH and AST. Hence, we demonstrated, that amount of sucrose in the diet influences metabolism and life span. Low carbohydrate consumption may cause calorie restriction conditions. Reduced food intake without malnutrition has been shown to extend lifespan in different model organisms [22, 23]. Calorie restriction is associated with a decreased glucose level, and as a result insulin signaling (IS) inhibition [24]. Degreased IS affects other signaling pathways involved in lifespan regulation. Under IS inhibition dFOXO (Forkhead box proteins class 'O') remains unphosphorylated and is transported to the nucleus where it activates expression of prolongevity genes [25].

It is known, that organism uses carbohydrates mostly for energy production. AMPK is a key sensor of cellular energy levels and is an upstream regulator of both the target of rapamycin (TOR) and IS pathways under low-nutrient conditions [26]. Activated AMPK inhibits energy-consuming processes, such as protein synthesis, through the inhibition of TOR signaling under low-energy conditions (high AMP:ATP ratio) [27]. Numerous studies demonstrated, that IS and TOR signaling inhibition caused lifespan extension in various animal models [28].

Lowering yeast concentrations in the diet has been shown to extend Drosophila lifespan [4], sug- 
gesting that protein is the major specific nutrient responsible for modulating lifespan and ageing processes [15, 29]. Carbohydrates were not show to have significant effects on lifespan or their impact is too weak [3, 15]. However, recent findings have shown that dietary protein-to-carbohydrate ratio $(\mathrm{P}: \mathrm{C})$ in the food is a key determinant of Drosophila lifespan $[2,12,15]$. Our study revealed, that low sucrose content in the diet maximized female lifespan. Restriction of glucose and fructose consumption causes mild oxidative stress, which may increase protective potential in Drosophila's body [7]. Sucrose is a disaccharide, which consists of glucose and fructose residues. Glucose induces toxicity when circulating in high concentrations, whereas fructose is more prone to induce obesity promoting accumulation of reserve lipids and carbohydrates [7]. In our study, we observed decreased survival of females reared on the medium with high sucrose content that may be associated with hyperglycemia and/or obesity induction.

We also tested how sucrose concentration in the diet influences carbohydrate metabolism. Metabolic changes can be estimated by lactate dehydrogenase (LDH) activity. This activity indicates the predominance of anaerobic versus aerobic metabolism in particular tissues [30]. LDH catalyzes the oxidation of lactate to pyruvate when there are high concentrations of lactate and reverse reaction of the reduction of pyruvate to lactate occurs in case of oxygen deficiency in the cell. An increase in LDH activity may reflect the hypoxic conditions in the body [31]. $\mathrm{MDH}$ activity indicates overall metabolic status. This enzyme plays an important role in the TCA cycle, and MDH is involved in glucose oxidation. It is known, that decrease in the activity of cytosolic $\mathrm{MDH}$ reflects repression of energy metabolism [32]. Our investigation indicates that high sucrose content in diet leads to a decrease in the activity of MDH. Production of oxaloacetic acid in the reaction catalyzed by MDH may depend on the concentration of energy substrates. So, sufficient carbohydrate supply inhibits gluconeogenesis and MDH activity as a result.

Besides carbohydrate metabolism, we suggested, that dietary sucrose may have impact on amino acid metabolism. Aminotransferases are known to play a key role in the intermediary metabolism of amino acids. ALT and AST take part in maintenance of amino acid pool for protein synthesis. They supply metabolites for energy metabolism and provide interactions between protein and carbohydrate metabolism. Elevated AST and ALT activities can be considered as an index of gluconeogenesis [33]. ALT is responsible for reversible transamination between alanine and 2-oxoglutarate to generate pyruvate and glutamate, playing a key role in the metabolism of glucose and amino acids. AST catalyzes the interconversion of aspartate and $\alpha$-ketoglutarate to oxaloacetate and glutamate. Incorporation of $\alpha$-ketoglutarate into the TCA cycle is the major step critical for the production of building blocks including nucleotides, lipids and amino acids. It is generally suggested that an increase in the activities of ALT and AST indicates metabolic disorder in various insects [33]. In our investigation we did not observe any changes in ALT activity compared to control in both sexes. We observed a decrease in AST activity in flies when consuming diets with high sucrose content that may be explained by activation of gluconeogenesis under well fed state. Our data show that low sucrose content in the diet, on the contrary to high sucrose, increases AST activity with subsequent likely involvement of gluconeogenesis.

Urea derives from nitrogen metabolism, protein degradation and amino acids catabolism, and at high concentrations is toxic to organism. The level of urea is markedly affected by both protein content in the diet and protein catabolism rate [19]. Urea is an important scavenger of free radicals in biological systems, including insects [14, 34]. Hilliker and colleagues (1992) have found that urate is crucial in antioxidative defense in vivo in D. melanogaster. Low-protein intake is associated with reduced urea production. Our results show that consumption of the diet with high carbohydrate concentration increase urea content in females. In addition, low sucrose consumption in male flies leads to protein catabolism with increased urea production.

Thus, low sucrose consumption leads to carbohydrate starvation. Since sucrose is a food source of glucose and fructose, both monosaccharides are fed into glycolysis. Under low sucrose consumption, we observed higher LDH activity, which causes a shift to anaerobic metabolism. High MDH activity under low sucrose consumption may lead to enhanced OA production, and, as a result, gluconeogenesis activation. High AST activity under low sucrose diet may lead to enhanced malate $\rightarrow \mathrm{OA}$ production, and consequently to gluconeogenesis activation. We observed also higher urea content under low sucrose consumption, which may indicate enhanced amino acids metabolism. We found some nutrient- 
dependent changes in the intermediate metabolism of Drosophila melanogaster and provided evidence about coupling changes in the activity of metabolic enzymes and organismal life span.

Conflict of interest. Authors have completed the Unified Conflicts of Interest form at http://ukrbiochemjournal.org/wp-content/uploads/2018/12/ coi_disclosure.pdf and declare no conflict of interest.

\section{ВМІСТ САХАРОЗИ У ДІЕТІ ЯК ВИЗНАЧАЛЬНИЙ ФАКТОР МЕТАБОЛІЗМУ ТА ТРИВАЛОСТІ ЖИTTЯ DROSOPHILA}

\author{
О. Стрільбицька, Т. Струтинська, \\ У. Семанюк, Н. Бурдилюк, О. Лущак
}

Прикарпатський національний університет імені Василя Стефаника, Івано-Франківськ, Україна;

凶e-mail: oleh.lushchak@pnu.edu.ua

Харчування впливає на різні аспекти життєдіяльності. Ми використали плодову мушку Drosophila melanogaster як модельний об'єкт для встановлення впливу вмісту сахарози в їжі на перебіг метаболічних процесів та тривалість життя. Мух утримували на дієтах із концентрацією сахарози в межах від 1 до $20 \%$ та сталим вмістом дріжджів. Виявлено, що низький вміст сахарози у харчовому раціоні самок продовжує їх тривалість життя. Також продемонстровано, що зниження споживання сахарози призводить до підвищення активності малатдегідрогенази, аспартат амінотрансферази в самців, а також лактат дегідрогенази в самок. Навіть більше, вуглеводний склад харчового раціону впливає на вміст сечовини, що свідчить про те, що вуглеводи дієти впливають на загальний обмін речовин. Наші результати продемонстрували значний вплив сахарози в їжі на активність основних ензимів метаболічних шляхів та виявили оптимальні харчові умови для досягнення довголіття.

К л ю чов і слов а: харчування, дієта, вуглеводи, тривалість життя, обмін речовин, плодова мушка Drosophila.

\section{References}

1. Lushchak OV, Rovenko BM, Gospodaryov DV, Lushchak VI. Drosophila melanogaster larvae fed by glucose and fructose demonstrate difference in oxidative stress markers and antioxidant enzymes of adult flies. Comp Biochem Physiol A Mol Integr Physiol. 2011; 160(1): 27-34.

2. Lushchak OV, Gospodaryov DV, Rovenko BM, Glovyak AD, Yurkevych IS, Klyuba VP, Shcherbij MV, Lushchak VI. Balance between macronutrients affects life span and functional senescence in fruit fly Drosophila melanogaster. J Gerontol A Biol Sci Med Sci. 2012; 67(2): 118125.

3. Grandison RC, Piper MD, Partridge L. Aminoacid imbalance explains extension of lifespan by dietary restriction in Drosophila. Nature. 2009; 462(7276): 1061-1064.

4. Mair W, Piper MD, Partridge L. Calories do not explain extension of life span by dietary restriction in Drosophila. PLoS Biol. 2005; 3(7): e223.

5. Lushchak OV, Gospodaryov DV, Rovenko BM, Yurkevych IS, Perkhulyn NV, Lushchak VI. Specific dietary carbohydrates differentially influence the life span and fecundity of Drosophila melanogaster. J Gerontol A Biol Sci Med Sci. 2014; 69(1): 3-12.

6. Matzkin LM, Johnson S, Paight C, Bozinovic G, Markow TA. Dietary protein and sugar differentially affect development and metabolic pools in ecologically diverse Drosophila. J Nutr. 2011; 141(6): 1127-1133.

7. Rovenko BM, Perkhulyn NV, Gospodaryov DV, Sanz A, Lushchak OV, Lushchak VI. High consumption of fructose rather than glucose promotes a diet-induced obese phenotype in Drosophila melanogaster. Comp Biochem Physiol A Mol Integr Physiol. 2015; 180: 75-85.

8. Bai Y, Li K, Shao J, Luo Q, Jin LH. Flos Chrysanthemi Indici extract improves a highsucrose diet-induced metabolic disorder in Drosophila. Exp Ther Med. 2018; 16(3): 25642572. 
9. Rovenko BM, Kubrak OI, Gospodaryov DV, Perkhulyn NV, Yurkevych IS, Sanz A, Lushchak OV, Lushchak VI. High sucrose consumption promotes obesity whereas its low consumption induces oxidative stress in Drosophila melanogaster. J Insect Physiol. 2015; 79: 42-54.

10. Cantó C, Auwerx J. Calorie restriction: is AMPK a key sensor and effector? Physiology (Bethesda). 2011; 26(4): 214-224.

11. Oldham S, Hafen E. Insulin/IGF and target of rapamycin signaling: a TOR de force in growth control. Trends Cell Biol. 2003; 13(2): 79-85.

12. Semaniuk U, Feden'ko K, Yurkevych IS, Storey KB, Simpson SJ, Lushchak O. Withindiet variation in rates of macronutrient consumption and reproduction does not accompany changes in lifespan in Drosophila melanogaster. Entomol Exp Appl. 2018; 166(1): 74-80.

13. Rovenko BM, Perkhulyn NV, Lushchak OV, Storey JM, Storey KB, Lushchak VI. Molybdate partly mimics insulin-promoted metabolic effects in Drosophila melanogaster. Comp Biochem Physiol C Toxicol Pharmacol. 2014; 165: 76-82.

14. Lozinsky OV, Lushchak OV, Kryshchuk NI, Shchypanska NY, Riabkina AH, Skarbek SV, Maksymiv IV, Storey JM, Storey KB, Lushchak VI. S-nitrosoglutathione-induced toxicity in Drosophila melanogaster: Delayed pupation and induced mild oxidative/nitrosative stress in eclosed flies. Comp Biochem Physiol A Mol Integr Physiol. 2013; 164(1): 162-170.

15. Bruce KD, Hoxha S, Carvalho GB, Yamada R, Wang HD, Karayan P, He S, Brummel T, Kapahi P, Ja WW. High carbohydrate-low protein consumption maximizes Drosophila lifespan. Exp Gerontol. 2013; 48(10): 1129-1135.

16. Lushchak O, Strilbytska O, Piskovatska V, Storey KB, Koliada A, Vaiserman A. The role of the TOR pathway in mediating the link between nutrition and longevity. Mech Ageing Dev. 2017; 164: $127-138$.

17. Mera JR, Dickson B, Feldman M. Influence of gender on the ratio of serum aspartate aminotransferase (AST) to alanine aminotransferase (ALT) in patients with and without hyperbilirubinemia. Dig Dis Sci. 2008; 53(3): 799-802.
18. McGill MR. The past and present of serum aminotransferases and the future of liver injury biomarkers. EXCLI J. 2016 ;15:817-828.

19. Watford M. The urea cycle: Teaching intermediary metabolism in a physiological setting. Biochem Mol Biol Educ. 2003; 31(5): 289-297.

20. Hamberg O. Regulation of urea synthesis by diet protein and carbohydrate in normal man and in patients with cirrhosis. Relationship to glucagon and insulin. Dan Med Bull. 1997; 44(3): 225-241.

21. Lee KP. Dietary protein:carbohydrate balance is a critical modulator of lifespan and reproduction in Drosophila melanogaster: a test using a chemically defined diet. J Insect Physiol. 2015; 75: 12-19.

22. Kenyon C. A pathway that links reproductive status to lifespan in Caenorhabditis elegans. Ann N Y Acad Sci. 2010; 1204: 156-162.

23. Tatar M. The plate half-full: status of research on the mechanisms of dietary restriction in Drosophila melanogaster. Exp Gerontol. 2011; 46(5): 363-368.

24. Masoro EJ. Overview of caloric restriction and ageing. Mech Ageing Dev. 2005; 126(9): 913922.

25. Puig O, Marr MT, Ruhf ML, Tjian R. Control of cell number by Drosophila FOXO: downstream and feedback regulation of the insulin receptor pathway. Genes Dev. 2003; 17(16): 2006-2020.

26. Kahn BB, Alquier T, Carling D, Hardie DG. AMP-activated protein kinase: ancient energy gauge provides clues to modern understanding of metabolism. Cell Metab. 2005; 1(1): 15-25.

27. Shaw RJ, Kosmatka M, Bardeesy N, Hurley RL, Witters LA, DePinho RA, Cantley LC. The tumor suppressor LKB1 kinase directly activates AMP-activated kinase and regulates apoptosis in response to energy stress. Proc Natl Acad Sci USA. 2004; 101(10): 3329-3335.

28. Kapahi P, Zid BM, Harper T, Koslover D, Sapin V, Benzer S. Regulation of lifespan in Drosophila by modulation of genes in the TOR signaling pathway. Curr Biol. 2004; 14(10): 885890.

29. Min KJ, Tatar M. Restriction of amino acids extends lifespan in Drosophila melanogaster. Mech Ageing Dev. 2006; 127(7): 643-646.

30. Granchi C, Bertini S, Macchi M, Minutolo F. Inhibitors of lactate dehydrogenase isoforms and their therapeutic potentials. Curr Med Chem. 2010; 17(7): 672-697. 
31. Lukacova S, Sørensen BS, Alsner J, Overgaard J, Horsman MR. The impact of hypoxia on the activity of lactate dehydrogenase in two different pre-clinical tumour models. Acta Oncol. 2008; 47(5): 941-947.

32. Müller M, Mentel M, van Hellemond JJ, Henze K, Woehle C, Gould SB, Yu RY, van der Giezen M, Tielens AG, Martin WF. Biochemistry and evolution of anaerobic energy metabolism in eukaryotes. Microbiol Mol Biol Rev. 2012; 76(2): 444-495.
33. Sookoian S, Pirola CJ. Alanine and aspartate aminotransferase and glutamine-cycling pathway: their roles in pathogenesis of metabolic syndrome. World J Gastroenterol. 2012; 18(29): 3775-3781.

34. Hilliker AJ, Duyf B, Evans D, Phillips JP. Uratenull rosy mutants of Drosophila melanogaster are hypersensitive to oxygen stress. Proc Natl Acad Sci USA. 1992; 89(10): 4343-4347. 